Etnográfica

Revista do Centro em Rede de Investigação em

Antropologia

vol. $14(2) \mid 2010$

Vol. $14(2)$

\title{
Afro-Brazilian religions in Portugal: bruxos, priests and pais de santo
}

Religiões afro-brasileiras em Portugal: bruxos, padres e pais de santo

\section{Clara Saraiva}

\section{(2) OpenEdition \\ Journals}

Electronic version

URL: https://journals.openedition.org/etnografica/292

DOI: $10.4000 /$ etnografica.292

ISSN: 2182-2891

\section{Publisher}

Centro em Rede de Investigação em Antropologia

Printed version

Date of publication: 1 June 2010

Number of pages: 265-288

ISSN: 0873-6561

\section{Electronic reference}

Clara Saraiva, "Afro-Brazilian religions in Portugal: bruxos, priests and pais de santo", Etnográfica [Online], vol. 14 (2) | 2010, Online since 20 July 2012, connection on 10 February 2022. URL: http:// journals.openedition.org/etnografica/292 ; DOI: https://doi.org/10.4000/etnografica.292

\section{(c) (7) \&}

Etnográfica is licensed under a Creative Commons Attribution-NonCommercial 4.0 International License. 


\section{Afro-Brazilian religions in Portugal: bruxos, priests and pais de santo ${ }^{1}$}

\section{Clara Saraiva}

The Afro-Brazilian religions that established themselves in Portugal during the last twenty years are becoming more and more popular. The temples are full with Portuguese followers that, after going through the initiation processes, become important in the organization of the religious community and, with time, may themselves become priests. Most of them previously believers in the Catholic church, their turning towards the Afro-Brazilian cults most of the times does not keep them from sustaining their regular church-going practices. As such, many prefer Umbanda, closer to the Catholic matrix, while others turn to Candomblé and to African performances, which are rather new to them. Drawing on field work conducted in Lisbon, in temples and with followers of these cults, and on the pioneer work of Ismael Pordeus Jr., this paper explores some of the aspects of this new "Portuguese" syncretism, the way these cults incorporating possession appeal to the Portuguese, and the hermeneutical process of Brazilian influences in Portugal and returning to their roots again, linking the three corners of the Portuguese Black Atlantic.

KEYWORDS: Umbanda, Candomblé, Portugal, transnational religions, immigration, re-africanization.

Maria, a woman in her late fifties, and her daughter, 23 years old, came from Lamego, a city in the northern interior part of Portugal, to attend the ceremonies and consultations at one of the terreiros of Umbanda in the Lisbon area. Although the trip was long (more than three hours by train), they thought it

l Research was conducted through the project "Políticas de Saúde e Práticas Terapêuticas: Sofrimento e Estratégias de Cura dos Migrantes na Área da Grande Lisboa”, funded by FCT (PTDC/ANT/65857/2006), and an earlier version of this paper was published in German (Saraiva 2010). I dedicate this article to Ismael Pordeus Jr., who led me to discover the beauty of Afro-Brazilian religions. 
was worth their while. Both the daughter and the father (who did not come for consultation) had been suffering from several diseases in the previous three years, and had been consulting a bruxo ${ }^{2}$ in the Lamego area. Feeling that things were not getting any better, they heard of the reputation of the pai de santo ${ }^{3}$ of this Umbanda terreiro ${ }^{4}$ and decided to come for consultation. Pleased with the first consultation, they returned several times, and acknowledged the virtues of this man, who, in their words, "was a powerful healer, and worked a lot better than the bruxos they had been consulting for years".

$S$. is a 52 year-old woman, born in Angola, from an Angolan mother and a Portuguese father. She lived there all her childhood and came to Portugal to conduct medical studies at the university level. $S$. had had manifestations of mediumship all her life, from early childhood on, first in Angola and then in Portugal. She and her family used the services of several experts in divination by cards, as well as some of the basic healing therapies, through the use of plants, libations and candles. Meanwhile, in one of her trips back to Angola, one of the young women in her family made the acquaintance of a man, also from Angola, who lived there and was very skilled in the art of divination through card and shell throwing. This man went to Brazil where he pursued this activity, and, in between trips to Brazil and Angola, decided, instigated by this group of Angolan women, to come to Portugal "to work". Once in Lisbon, he became known as a reliable card and shell thrower, and after two years he founded a small terreiro that these women started to frequent. It was thus in this terreiro that $S$. had her first cases of trance inscribed in a group that supported her experiences, and thus allowed her to express her mediumship. She, her family and friends stayed in this terreiro for a few years, but things did not go very well. Disagreements with the pai de santo started and the followers begun doubting his truthfulness and capacity to enter into altered states of consciousness through trance. Another source of conflict was the fact that they felt this pai de santo never explained what was happening, the reasons for each ritual and healing therapies, the religious basis behind them, etc. They started buying books about Umbanda and Spiritualism and learning on their own about the theological grounding for what they were doing. After several problems, this whole group left the terreiro and continued with their religious practices on a very private basis, at their own homes. Through the Internet, $S$. then found a pai de santo based in Madrid, Spain, who had already founded a terreiro and seemed willing to help her and her group. This pai de santo started coming

2 A bruxo is a sorcerer or diviner who attends to life-crisis situations.

3 Pai/mãe de santo means, literally, "father" or "mother of the saint", and refers to the ritual leader, the cult priest/priestess. Their followers are called filho/filha de santo, literally "son/daughter of the saint".

4 In the Afro-Brazilian cults, terreiro refers both to the physical temple and the congregation of initiated and followers of these cults. 
to Portugal once a month (and later on every fortnight) to found and organize a terreiro here. In time, $S$. passed her bori and feitura $;{ }^{5}$ her initiation ceremonies took place in Madrid, in the "mother" terreiro. When she passed her decá (seven year obligation, which allows the person to act as a priest/priestess) and became herself a mãe de santo, able to perform healing ceremonies herself and initiate her own followers, several of the filhos and filhas de santo from Madrid came to participate in the ceremony.

\section{NEW CULTS AND NEW THERAPIES IN PORTUGAL}

The terreiro where Maria and her daughter found relief for their ailments and the one where $S$. was able to enact her mediumship, are only two of the over forty existing nowadays in Portugal, showing the success of the Afro-Brazilian cults within the wave of new religions and cult movements that appeared in the country after the 1974 revolution and, especially, with the recent immigration waves.

Immigration has changed the face of the country, which became the locus of a multicultural and multiethnic society, ${ }^{6}$ also from a religious point of view, as the new religions that emerged are now protected by the 2001 law concerning religious freedom. At the onset of the twenty-first century, Portugal has Jews, Islamic groups (mainly Sunits and Ismaelis), Evangelical churches (such as the Church of the Nazarene), several Pentecostal and Neopentecostal churchs (including IURD, ${ }^{7}$ Assembly of God and Maná churches), some African churches (as the Kimbanguists, ${ }^{8}$ for instance) and animistic practices brought by a variety of African migrants (Bastos and Bastos 2006; Vilaça 2001; Mafra 2002; Pordeus Jr. 2000, 2009; Saraiva 2007, 2008). Many of these religious constructs or movements appear as new forms of cult that present themselves as alternative therapeutic practices attending to life-crisis situations (Saraiva 2007); such is the case of the Afro-Brazilian cults.

Thus, the Portuguese have nowadays a richer religious and therapeutic world available to them based upon alternative approaches: alternative not only to the classical biomedical Western perspective, but also to the traditional field of the so-called "popular religion", which existed side by side with the Catholic practices and included the consultation of spirits through the work

5 Bori and feitura are both initiation rituals that individuals have to go through to be able to incorporate the entities.

6 Research on the recent condition of the country as a host-nation for immigrants from other continents has been published by several authors (see Barreto 2005; Bastos and Bastos 1999, 2006; Gusmão 2004; F. Machado 2002; Malheiros 2005; Padilla 2003; Pires 2003; Quintino 2004; Vala 1999).

7 IURD stands for Igreja Universal do Reino de Deus (Universal Church of the Kingdom of God).

8 Research on Kimbaguist and Takoist churches in Portugal is currently under course by Ramon Sarró and Ruy Blanes (see Sarró 2009; Blanes 2009). 
of intermediaries between the world of the living and the one of the dead - or intermediaries in the relation with the supernatural world as a whole-, common in the Southern Mediterranean European countries, such as the "sorcerer", "witch", corpo aberto or others, of which the classical work of Jeanne FavretSaada (1977) gives a full account. ${ }^{9}$

Based on research with religious leaders and followers of the Afro-Brazilian cults in Portugal, this text highlights not only the essence of transnational religions and the relationships they encompass, but also hidden aspects of the confrontation with different worldviews that diasporic movements and globalization induce (Koser 2003), and which have implications on the religions and ritual therapies people abide to.

I will argue that the success of the Afro-Brazilian cults in Portugal must be understood in the context of the attraction towards a new religion that allows for more individual visibility, but at the same time does not clash with previous beliefs and ways of solving life-crisis situations. The adaptations of such cults to the contemporary Portuguese context, in which Portuguese and migrants from different backgrounds are present, will also be discussed, most particularly regarding the way the religious continuum that characterizes these religions, from the ones closer to the Catholic matrix to the more African variants, is re-constructed in Portugal, as Ismael Pordeus Jr. (1998, 2000) suggests, and how their transnational aspects become emphasized as a means of empowerment for both the cult leaders and the practitioners.

\section{"OMULU IN LISBON"}

In an article published in 2001, named "Omulu in Lisbon: ethnographies towards a theory of globalization", Cristiana Bastos portraits the reality of a new multicultural Lisbon (where an area of the old city had been taken over by immigrants and their shops, thus presenting a much richer scenario than twenty years before), leading her into a discussion on the concepts of de-territorialization, transnationalism and globalization. She argues that, in the present world, such concepts are in constant mutation, and, specially, the world itself is changing and universes as different as magical African rituals and McDonald's fast-food restaurants are only a doorstep away. Relating such concepts to issues in medical anthropology, this micro-ethnography of contemporary urban Lisbon shows the ways in which "different systems of beliefs and practices of health and illness overlap and intertwine" (Bastos 2001: 323), and how different ways of managing health and affliction are portrayed in a particular street where a medical school, a hospital, the morgue, funeral homes 
and a shopping centre constituted of ethnic shops converge. From the medical school to the cult of a spirit doctor, venerated in a statue placed right in front of the school, to the Chinese shops advertising ointments for several ailments, a ritual healer from Guinea-Bissau offering help through the handling of the sacred Koran, stores within the commercial centre showing African and Indian products, and a shop selling all sorts of esoteric and new age paraphernalia as well as statues of the Brazilian orixás, ${ }^{10}$ side by side with the various Catholic saints, a whole world of variety and ethnic mix is present.

Deriving the title of her article from the Afro-Brazilian god of sickness and health (Omulu), the author concludes emphasizing the way in which, in our contemporary interactive world, such practices are consumed and multiply side by side, and stresses the urgent need for more ethnographies in order to better comprehend such interactions, which engage issues of tension, power, and show the fragilities of this new world order (Bastos 2001: 322).

The reality depicted in this article, written in 2000, has changed over the past nine years. Nowadays, what is listed in the Portuguese newspapers and Internet advertisements as the "esoteric" field is only one of the visible faces of such diversity: specialists that publicize their expertise in tarot card games, shell games, consultations to solve all problems related to wealth, love or health, invoking either their training in Brazil or in Africa; esoteric shops named "The occult world", "Mystic world" or "The Xangô warehouse", ${ }^{11}$ where one can find everything, from African herbs and "magical powders" to make someone love you, candles to be lighted in veneration to a certain saint when a daughter is undergoing her final university exams, reiki and feng-shui manuals, as well as many other books concerning new healing techniques of aromatherapy, gemotherapy, chromotherapy and quantic healing. Both in newspapers and on the Internet new religious movements and cults publicize their services and doctrine, emphasizing aspects from praying to microscopic analysis, from IURD to the "New church of our all mighty body". This last one, for instance, shows a virtual on-line mass, consulting-room and surgery possibilities, as well as a catalogue of merchandise where the opening page portraits an American physics laboratory of the 50s, with the scientist looking through a microscope and wearing an impeccable white gown.

Amongst all these media and Internet advertisings, the Afro-Brazilian cult houses (Umbanda and Candomblé) are largely publicized, and the terreiros often have a website where the doctrinal lines of the temple are stated, together with directions on how to arrive there, schedules and obligations the persons

10 The orixás are deities from Yoruba origin, which became the symbol/trademark for Candomblé in Brazil.

11 Large store selling magical products used in the Umbanda and Candomblé cults, named after one of the orixás. 
must fulfill to attend the sessions. Thus, the Afro-Brazilian cults are now part of this new esoteric field, and the cult houses are expanding rapidly.

Let us now look at the way they entered the country and how they settle today as an important cult option for the Portuguese, as part of the phenomenon of re-composition of the religious field that accompanied the migration movements.

\section{IEMANJÁ IN PORTUGAL}

From being a country of immigration, Brazil became, in the course of the 1980s and 1990s, an exporter of individuals, due to internal economic, social and political turmoil. A series of factors helped to create the idea of Portugal as an ideal place to migrate to, where integration would be easy, due to factors such as language, culture, and a common past, based on colonial relations and the long, historical and rhetorically constructed idea of special Luso-Brazilian relations (Feldman-Bianco 2001; I. Machado 2002; Padilla 2003). Attracted also by the entrance of Portugal into the European Union, in 1990 there were 20.85 I legal Brazilians; between 2004 and 2006 the figures have ranged between 66.907 and 65.000 individuals, increasing in 2008 to a total of 106.961 individuals, which makes Brazilians the largest group of migrants in $2008-24 \%$ of the total migrant universe (SEF 2009: 28-29).

Long before the arrival of migrants, Brazil entered the Portuguese homes in the late 1970s, through television shows and Brazilian soap operas; two of them, based on some of Jorge Amado's books, portrayed the worlds of the Afro-Brazilian religions, Umbanda and Candomblé. ${ }^{12}$ The image of Iemanjá (one of the most important goddesses) is nowadays sold, side by side with the images of the Catholic Our Lady of Fatima (the better known and most important Catholic site of pilgrimage in Portugal) or other saints of the Portuguese Catholic pantheon, in the shops that sell religious and esoteric merchandises.

Also in the 1970s, a Portuguese woman who had been an emigrant worker in Brazil for decades, where she had joined the Umbanda cult, becoming fully initiated as a mãe de santo, returned to her country and, soon after the 1974 revolution, opened up her own terreiro and started to perform Umbanda rituals there. Almost twenty years later, Ismael Pordeus Jr. came to Portugal to study the history of this first terreiro and the following expansion of such cults. In Pordeus Jr.'s book, Uma Casa Luso-Afro-Portuguesa com Certeza (Pordeus Jr. 2000), which is centred on the life of this woman, Mãe Virgínia, collected through hundreds of hours of interviewing and interaction, she mentions how the Portuguese were, at this time, eager for all that was new, in the social and

12 Jorge Amado is one of the most famous Brazilian writers, whose books give interesting ethnographic-like portrays of Brazilian society. 
political areas, but also in the religious field, and how easy it was to find followers and people ready to attend and learn about these practices. Her first followers, filhas and filhos de santo, later on founded their own terreiros, thus spreading the practice of Umbanda and Candomblé cults.

With time, the Umbanda and Candomblé cults became known and spread all over the country. Brazilian immigration to Portugal brought along individuals claiming to be pais or mães de santo, who use their nationality as an authoritative claim to practice such cults. Nowadays, many terreiros can be found in the country, some of them with branches in the North, the Lisbon area and in the South.

\section{FROM CATHOLICISM TO AFRICAN PRACTICES}

The classical works by Roger Bastide and Pierre Verger expand on the history of how the cults of the different gods in the original African grounds were, through the slave trade, exported to the new world, developing into a wide variety of new syncretic cults, which encompass Brazilian Candomblé, Haitian Voodoo and Cuban Santeria, amongst others. In fact, in contemporary Brazil there is a large variety of cults - what Bourdieu (1971) refers to as the champ religieux, religious field -, from the Catholic and Kardecist-related Umbanda practices, to the more africanized Candomblé Keto, corroborating what several authors have recently written on the religious continuum of such Afro-Brazilian religious clusters (Camargo 1961; Capone 2004b; Frigerio 2004; Schmidt 2008). The differences relate more to the discourses and autonomy of the cult leaders and followers than to crucial oppositions in principles and rituals (Capone 2004a; Maggie 2001: 111 ), and in most cases these cults are themselves a mixture of practices, borrowing from different origins and traditions. The plasticity of such religions being one of its characteristics, it is especially put to proof in diaspora situations, where they have to adapt to new types of followers, new settings and new social and cultural circumstances (Frigerio 2004; Oro 1995; Pordeus Jr. 2000, 2009).

In Portugal, many terreiros are Umbanda ones, or follow a form of Umbanda integrating African elements, as in Umbanda Omolocô (Pordeus Jr. 2000, 2009); nevertheless, the tendency to state the relation of the pai or mãe de santo to Candomblé, as a way to stress the authenticity and value of his/her knowledge and power, is nowadays a clear trend. Many cult leaders are, therefore, first initiated in Umbanda and then, later on, in Candomblé, the latter being perceived to be closer to both the original African source, and to the historically linked creation of the Afro-Brazilian religions in Brazil. The tension between Umbanda practices, with a strong tendency to accentuate the Catholic side of their rites and performances, and the more African practices, integrating the sacrifice of animals, is one of the aspects relevant in 
the discussion of the impact of such new religions and therapeutic practices upon the Portuguese.

As A. Frigerio (2004: 44) puts it, we can consider the cults closer to that Catholic matrix as cognitive bridges between the folk Catholicism that is traditionally practiced and the more African variants that have some theological concepts and rituals that are unfamiliar to it. ${ }^{13}$ But we must also link Frigerio's idea of a cognitive bridge to Pordeus Jr.'s previous proposals of Umbanda Omolocô as a variety allowing the permanence of Portuguese esoteric practices. In his analysis he emphasizes how Omolocô places side by side the Candomblé and Umbanda pantheons, inverting the whitening movement that was so strong within Umbanda from the 1920s to the 1970s in Brazil.

The conditions for the development of Umbanda in the southern capitals of Brazil, in the 1920s, served nationalistic purposes and led to the expulsion of any elements that could be associated with blackness and Africa, thought of as "primitive" factors, not worthy of a nation progressing towards development and modernity (Birman 1985). ${ }^{14}$ The move towards a break with the Afro-Brazilian traditions (Brown 1999; Ortiz 1988) was therefore a struggle, led by a white elite, to include many rationalistic Kardecist approaches, and to appropriate Umbanda as a "truly Brazilian religion". Candomblé, related directly to Africa, would keep its animal sacrifices, the use of blood in many rituals and other features connected with the black, African descendent populations. ${ }^{15}$

Unlike Brazil, in Portugal, rather than centering the discussion on the "purity" of the cults (Dantas 1988), the preference tends to go towards the paradigm of a Portuguese "ideal" version, where representations and practices connect the three corners of the Atlantic - Portugal, Africa and Brazil - in a single symbolic unit, thus creating what Pordeus Jr. (as well as Guillot 2007) calls a Portuguese variant of the Afro-Brazilian cults.

In fact, Brazil appears here in a pivotal position, as the motherland, the origin of the Afro-Brazilian cults; all of a sudden, from regular churchgoers, Portuguese become assiduous frequenters of esoteric shops, buy books on Umbanda and Candomblé, and dream of going to a terreiro in Salvador da Bahia. ${ }^{16}$ Having gone there is a motive of pride and joy: "I went there last year, with my son! I had dreamt of doing this from the moment, three years ago,

13 For further discussion on the familiar or impenetrable elements and cognitive aspects of the AfroBrazilian religions, see Goldman (2007: 103-119).

14 The relationship between religion and ethnicity, race and class in Brazil is thoroughly discussed by Fry $(1982,2005)$.

15 The tensions between these two opposite approaches are still present nowadays, and involve discussion about the re-africanization and the purity of the cults in other variants of Candomblé, as in Candomblé Angola (Previtalli 2008; Ortiz 1988).

16 City in Northeast Brazil, considered the home of the Afro-Brazilian cults, especially Candomblé. 
when I started coming to this terreiro, here in Portugal. I wanted to go to the source. It was a wonderful experience!" [Sara, 55 years old, clerk]

In a country with such a high number of Brazilian immigrants the first assumption, when I started my research, was that such temples would be full of Brazilians, looking for practices in their diaspora that they eventually knew from their homeland. ${ }^{17}$ On the contrary, what happens in the terreiros, even those following different cult lines, is that both initiated who incorporate the spirits (filhos e filhas de santo) and clients are almost exclusively Portuguese middle-class individuals, and very few Brazilians frequent them, preferring to join Neopentecostal churches. This directly relates to the stereotypes and stigmatization that Brazilians feel in Portugal; stating that the Portuguese would look down on them if they would be known to frequent Umbanda or Candomblé cults, they prefer to ignore this possibility: "If the Portuguese thought we engage in feitiçaria [witchcraft], they would downplay us even more..."

In a context of supposed "brotherhood" and affinities between the two cultures (Feldman-Bianco 2001), it is striking how one stereotype mirrors the other and entirely inverts the situation: attracted both by the exotic side of the Afro-Brazilian cults and by its supposed closeness to their Catholic matrix, it is the Portuguese who feel the appeal of Iemanja and become followers of those religions. Let us now look at the reasons why this happens.

The sessions at the terreiros are festive and colourful. Umbanda coexists harmoniously with Catholicism; most of the practitioners were baptized and are regular churchgoers. Portuguese feel proud of their new religion, that they consider quintessentially Brazilian, yet without going against or somehow disturbing the doctrine of their Catholic matrix. This is emphasized by the people who talk of the figure of Father Oxalá ${ }^{18}$ as being Jesus Christ, of the principles of Umbanda as "peace and love in the world", and the importance of practicing charity, just as dictated by God. They conceptualize it as a religion of goodness and light, where people meet each other in harmony. The spiritualist side of Umbanda is also very appealing, since through its mediums the spirits offer aid and counsel, attending to life-crisis situations.

Thus, exotic, but not too exotic to the extent that they can be refused, Umbanda rituals may be thought of as a way to express emotions and paradigms that were excluded by the Catholic matrix (Pordeus Jr. 2000). Umbanda offers individuals an opportunity to communicate directly with the other world, and be an active partner in all the rituals. The pontos, sang to summon the spirits, are intoned by all participants with a Brazilian accent, but nevertheless often emphasizing a melody closer to the Catholic chants. The lyrics

17 As Luís Silva Pereira (2006) also notes.

18 Oxalá is considered by many the most important orixá in the Afro-Brazilian religions, equivalent to Jesus Christ in the Catholic religion. 
in the pontos clearly accentuate the messages of light, peace and love, appealing to a Catholic population; the sites in the Internet advertising the terreiros or the consultations insist on these messages of love and brotherhood. The concept of conversion is therefore much more flexible than the same notion within the Protestant or Pentecostal churches, since the adherence to the AfroBrazilian cults does not mean people have to abandon their original Catholic beliefs and practices; rather, these are reinterpreted and readapted (Capone and Teisenhoffer 2001-2002: 1 1). If this holds true for the Umbanda terreiros, it also does for the Candomblé cults, and constitutes one of the particularities of the re-composition of the "religious continuum" of these cults in Portugal.

Based on the foregoing analysis we can systematize the reasons for the success of these Afro-Brazilian religions among the Portuguese, following Ari Oro's suggestions (Oro 1995), concerning their nature and the use that people make of them.

They are religions of affliction, that attend to life-crisis situations. As such, most of the times adherence to these religions starts with consultations to overcome afflictive situations related to health, love or financial troubles. Afterwards, people keep returning to continue therapies and often end up more involved in the group and even becoming initiated. In this perspective they often reinterpret their problems through the lenses of their new appurtenance, and by reviewing their cognitive maps of rejection/inclusion within certain worldviews. In this new approach directly connected to their adoption of the new cults, healing and the solution for crisis are attributed to the conversion to the cult of the orixás.

One of my informants, a young woman in one of the Lisbon Candomble terreiros who suffered from troubles since childhood, hearing voices and seeing spirits, was diagnosed in her adolescence as suffering from bipolar disorder, and underwent psychiatric treatment. Later, she started going to a Brazilian therapist and ended up in a Candomblé terreiro, where she started the initiation process to become a filha de santo. When she was diagnosed with breast cancer, she turned to a mixture of esoteric healing through magnetism, stone therapy and gemotherapy. But, most of all, she defends that what really worked was the help of the orixás:

When they first discovered the cancer, the doctors did not want to operate because the cancer was too big, and I had to undergo chemotherapy, and in four months the cancer went from 10 to 5 centimeters. When I started the chemo it was also when I paid the first obligations to my orixá. When I started the initiation ceremonies the cancer was 12 centimeters; in a few days it decreased to 10 centimeters, and the pain and bleeding ceased. After the operation the doctor told me I would never be able to move my arm again. Two weeks after I received Ogum (my head orixá) and from that 
day on I was able to move my arm in all directions, as if nothing had ever happened. I am sure I would have died if it was not for the orixás. [Laura, 31 , unemployed]

Being tolerant, these religions do not imply abandoning former religious practices. As we saw in the example of the woman from Lamego and her daughter, people feel they can go to the terreiro on Saturday and to the Catholic temples on Sundays without any clash. The ideology of Umbanda, for instance, based on the principles of charity and doing well to others, is felt as a continuation of Catholic practices. The possibility of helping others by using one's capacity to incorporate certain entities is also valued: "Although I am not conscious, I know my preto velho ${ }^{19}$ comes and he helps people. I feel very happy to be able to do something to heal people, although indirectly." [Lisa, 45, psychologist]

They are religions of seduction with an enchanted representation of humans, cultivating the mysterious aspects of their performances (Oro 1995). This feature, concerning the empowerment that trance allows for, is shared by Umbanda and Candomblé alike, and is central to an understanding of the success of these cults in Portugal. Portuguese interviewees talk about their experience in trance as an exhilarating one, that has changed their lives:

All my friends in the terreiro that see my pomba gira ${ }^{20}$ tell me how nice and funny she is, and how she helps women getting over their ailments. I have even asked them to take a photo of her when she incorporates me, so that I can have an idea what she looks like. I know it is my body, but one does not know what happens: the time-lapse of incorporation is like a blank [...] I just feel a little trembling and dizzy afterwards, but at the same time one has a great feeling of peace and having done something worthwhile, being incorporated by such important entities. [Ana, 24, university student]

They are also what several authors have called "emotional religions", in the sense that they allow for the individual expression of emotions and emotional catharsis in a way that the Portuguese value and feel that it was not allowed in the traditional Catholic scenario, as several interviewees have pointed out:

There is a great freedom, a total freedom, opening [...] one can laugh, play or cry, one feels entirely at ease when talking to the entities. And I

19 Preto velho: entity that personifies the old black slaves; they are conceived as very kind persons, experts in cure.

20 Pomba gira: the feminine counterpart of the exu, a trickster divinity; associated with prostitutes, pombas giras have a very liberal, even lascivious and obscene behaviour. 
think that everyone in the terreiro feels that, there are no constraints to openly show what one feels. Not like in the Catholic cults, where one has to just repeat the formulae and behave in a proper way, but never show our inner selves... [Lino, 26, security guard]

In Afro-Brazilian religions there is no censorship, but a total freedom to be and do what one wishes... [Caeser, 39, real estate agent]

Having both the individual and the collective aspect, they favor the construction of a personal and collective identity and trigger self-perceptions of integration into a group. The Saturday gatherings at the terreiros, where people bring drinks and food for a big collective meal after the end of the session, implies all the social aspects of commensality in ritual, when people come together in an informal way and feel that they "belong to a family, the família de santo":

When I come to spend my Saturdays in the terreiro I know that, besides the company of the spiritual entities, I will be with my spiritual family, whom I can share things with: the food we bring, but also our worries, our laughs. There is a good feeling of being together; since I joined the terreiro I never felt lonely again. [Joana, 35, clerk]

Finally, they are charismatic religions; the legitimization and reputation of a terreiro is measured by the strength and charisma of its priest/priestess, which, as we saw, brings us back to the relationship with migration and to the three corners of the Lusophone Black Atlantic - Africa, Portugal and Brazil.

\section{MIGRATING CULTS AND THERAPIES}

Now that we have seen how and why the Portuguese adhere to these religions, let us examine more closely the transnational aspects of these cults, through an analysis of the different ways in which migration and people's movements across the Atlantic play a role in their diffusion.

Afro-Brazilian cults are in fact making their way through Europe (with temples in Spain, France, Germany), and mainly using Portugal as their point of entrance. As we saw, it was the Portuguese migrants in Brazil who, in their return, brought such practices with them. Mãe Virgínia saw her temple and followers grow, in the 1980s and 90s, and the terreiros multiplied. Several of the Portuguese cult leaders who are still performing nowadays were initiated by this woman. But this was only the beginning of the movement of people, spirits and goods across the Atlantic. 
With time, an alternative way of forming cult houses in Portugal spread, founded by Brazilian cult leaders who came from "mother-terreiros" in Brazil and opened affiliated houses in Portugal and, in some cases, also in other European countries (Teisenhoffer 2007; Capone and Teisenhoffer 2001-2002). The pai de santo thus follows the guidelines of the original centre, with which he maintains a close relationship. Being overseas, nevertheless, allows for a certain freedom, and the terreiros differ in their organization and performances, following the general tendency - present even in their homeland, Brazil, as Stefania Capone (2004a) emphasizes - for each terreiro to have its own specificities.

Nevertheless, in both these cases, in order to assert his/her authority, a pai or mãe de santo has to reinforce the relationship with Brazil, either by being Brazilian, or, as a Portuguese, by having lived in Brazil, in order to acquire the knowledge and expertise necessary to perform his/her role. This also implies that they were - both Brazilians and Portuguese - initiated in the Afro-Brazilian cults in the Brazilian "motherland". Just like Africa appears as a symbolic paradise and a source of legitimization for the cults in the New World (Capone 2004a: 30), so too Brazil emerges in Portugal as the source of these AfroBrazilian cults, and as a strong means of empowerment. This empowerment works above all for the cult leaders, who must prove their efficiency and justify their reputation if they wish to enlarge the number of their followers. But it also plays a role in the conceptualization clients themselves make of the honesty of and respect for the cult leader. The close relation the priest/priestess has with Brazil, seen in the frequency of his/her travels or stays there, his/her connections with terreiros overseas, and the number of fellow cult leaders that come to Portugal to visit his/her cult house, are all indications of the prestige of the pai/mãe de santo.

Since religious identity is continuously negotiated amongst the social actors (Capone 2004a: 21), the fame of a terreiro is proportional to its success in the religious market: the larger the number of filhos de santo attracted by the force of the cult leader and his/her ability to manipulate the magical powers, the bigger the reputation. Each centre reflects the attitudes and performances of its cult leader, and people move on to another in case they are not satisfied with the pai or mãe de santo, or with any of the guidelines set for the terreiro, as we saw in the example given above in $S$. 's story. ${ }^{21}$ Besides, and most importantly, the prestige of a temple or cult leader relates to the fame of his/her performance as a healer. Apart from the cult house, most cult leaders also have private consulting-rooms where they receive clients: in fact, this is often the way

21 Related to this are the conflicts inside a terreiro, that often make people leave and go to another. See Yvonne Maggie's Guerra de Orixá for a full account of such conflicts and the idea that a terreiro may be seen as a symbolic system that represents certain aspects of the overall society (Maggie 2001: $119)$. 
people first approach these new cults. The newspapers and flyers advertising these consultations clearly emphasize the relation with Brazil "Mother $X$, having just come from Brazil...", or, "trained and initiated in Brazil in shell divination, oracles and tarot"), which wins them a lot of prestige and acts as a means of empowerment. Their therapeutic know-how is thus put to the test not only in the cult sessions but also in the private consultations, where a closer relationship with the patient/client is developed. In these consultingrooms the mixture of alternatives practices/healing traditions is present, and many show images of Catholic saints and orixás together; the priest/priestess are tarot cards and runes readers, as well as shell diviners, which they use to diagnose the client's problem, and masters of reiki, quantic healing and hypnosis techniques, which they use to cure. In the conceptualization the pais/mães de santo make of such combinations, everything is intertwined and permitted, all these techniques of healing are part of a whole, directed from the above by the Afro-Brazilian divinities, as one of them explained: "Our head is our guide. The orixás help us if we know how to handle them. Our head is our guide, the centre of everything, in Candomblé as in other therapies connected with the head, such as hypnosis and reiki..."

Besides the pais/mães de santo who own terreiros and give consultations, there are also a number of mães and pais de santo who have no cult houses in Portugal, and simply sell their therapeutic expertise, periodically travelling from Brazil to Lisbon in order to give consultations. They usually already have a regular clientele, and their fame is diffused by word of mouth from those who have already consulted them; they therefore do not generally advertise in newspapers or other media. As Pordeus Jr. (2006, 2009) stresses, using Turner's terminology, such cases illustrate the "anti-communitas", since these persons operate alone, without the ritual framing of a religious community: the consultations are personal, and there is no associated collective ritual. Such cases also show the importance of inter-individual networks that favor the diffusion of such transnational religions and the way these systems escape all sorts of state or official control (Capone and Teisenhoffer 2001-2002), as well as the importance of these transatlantic networks.

These persons are looked upon by the temple priests/priestess as "fakes", as merchants, i.e. people who sell things that cannot be sold, since the true cults are based on the principles of doing good and being charitable, expecting and receiving no remuneration for such actions. These aspects are symbolically re-structured and manipulated in people's own minds, according to the different situations: if it is accepted and even recommended that a cult leader continues his/her work by means of private consultations, not having had the power to create a religious community, or not even wanting to do so, is regarded as a sin. In fact, in the case of the "true" priests/priestess the consultations are always paid for and, besides being a steady source of income for the healer, they are 
used to cover current expenses related to the maintenance of the temple, such as monthly rents, gas and electricity bills, etc. The direct connection with the cult house and its community of followers legitimates those earnings.

Beyond the emphasized relationship with Brazil, a second affiliation that is claimed by the cult leaders is the connection to Africa. This relationship is mentioned in two instances: either by cult leaders who, as Mãe Virgínia, follow a hybrid vector of a cult, i.e. a form of Umbanda clinging more to the African aspects in Candomblé or, and often simultaneously, by the Portuguese priests/priestesses who, invoking their African background (a grandmother from Guinea or a mother from Angola), talk about how proud they are of such connection and how they learned values and practices from those forefathers. Right after the 1974 revolution, many Portuguese returned from the former colonies, especially from Angola and Mozambique, where ferocious civil wars started up. These people (named retornados, "those who returned") had an amazing impact in the Portuguese society: in a few months the population duplicated, and with them also came many new cult practices and therapies.

The story of $S$.'s family is one of such cases. Her mother, aunt and the rest of the family used to consult traditional healers in Angola, and I was told about several episodes of cure linked with the expertise of such healers. One of them is a good example to illustrate conceptions of illness and cure that circulated between Portuguese colonial Africa and the metropole. The story was told by $S$.'s aunt, whose daughter, at the age of one, became ill with some infected pustules under the skin; she traveled to Portugal for several dermatologist consultations but they were of no use; the mother was even told that there was no cure for such a disease: "One of the dermatologists I went to, being himself from Angola, asked why had I come here to treat the baby, since in Angola there were better ways to treat it, outside of Western medicine, and that there was no clinical cure here for such tropical disease." The family then turned to several traditional healers in Angola, but with no result. When the girl was already two years old, in a trip to the southern part of the country, the mother met an old lady who said she could cure her with some plants she had to collect before sunrise. She prepared an infusion which had to be applied to the face, and after a few months the girl was indeed healed. When she finally moved to Portugal, in the 80 s, $S$.'s aunt continued to consult traditional healers from her motherland, and later on joined the same terreiros as $S$.

The claim regarding the African presence in Portugal is part of Portuguese history from the XV century on, just as the link with Brazil, resting on the presence of black slave populations in Portugal (Lahon 1999) and on the Portuguese colonial presence in Africa. Used by historians and other social scientists, but also by the politics of intercontinental relations, it served as a basis for Gilberto Freyre's concept of luso-tropicalism (Castelo 1998), i.e. the idea that all lands connected by means of the Portuguese presence had something 
in common and could develop a certain ethos, only possible through the Portuguese presence and colonialism. This colonialism was thought to be different from that practiced by other nations and was allegedly based on good relations, the warm personality of the Portuguese and an open attitude that led to miscegenation between whites and blacks. This myth of a common past is rooted in the Portuguese self-imagery and is passed on to the ideology of the terreiros. For instance, in one of Mãe Virgínia's booklets, she states how the orixás, the inkises (Bantu divinities) and voduns (gods from Dahomey) are similar, since Africa, Brazil and Portugal constitute a unity. In her texts she expands on her theories about Umbanda Omolocô as a variety of Umbanda closer to the African matrix, since it is an intermediate ritual, between Umbanda and Candomblé Angola; this allows her to talk about her variation of Umbanda as a real African and original variety, enforcing her personal originality and creativity (both as a cult leader and as a healer), but at the same time linking the three continents (Pordeus Jr. 2000).

Just as occurred in the relationship with Brazil, the connection with Africa is also publicized in the media and on the Internet; there are radio and television programs with "professors" or "masters", mediums, diviners, fortunetellers and astrologers, recently arrived from Africa, who brought with them knowledge and techniques to give consultations and heal people in Portugal. Most of them have websites and appear in the newspapers in pages where, under the general "Esoteria" or "Occult Sciences" section, mães de santo and all such sorts of African healers are advertised.

\section{ADAPTATIONS IN WELL-BEING AND SICKNESS}

The process of transnationalization of the Afro-Brazilian religions in Europe triggers certain dynamics that show the need for adaptation to the new environment in which these religious systems find their new setting (Capone 2004b; Oro and Steil 1997).

People turn to consultations with ritual specialists and perform ritual therapies to solve life-crisis situations which generally express themselves through somatization; thus, the visible face of problems consists of health complaints, and ritual performances are strategies to attain or restore physical, mental and social well-being. As we have seen, this is one of the main reasons for the Portuguese to visit the terreiros, attracted by the reputation of the pai de santo as a therapist and the prestige that his terreiro gained. There is therefore a very practical side to the adherence to such religions, that directly connects to how individuals perceive what "being well" means. ${ }^{22}$ 
In the Afro-Brazilian religions, the conception of wellness entails an holistic perception of the person, where body and mind are intertwined, and healthy means being balanced (Barros and Teixeira 1989; Silva 1995; Brumana and Martinez 1991: 73). Sickness originates in an inadequate balance between forces that come from the supernatural and act upon the body. The notion of axé is central to this conception. Defined as an invisible, sacred and vital force present in all the deities, natural beings and things, this energy needs certain rituals to be dynamized. In the rituals, it is through the singing (pontos cantados), the beating of the drums and other performances that this force is activated, and that the spirits and supernatural entities are called upon.

Travelling across the Atlantic, the Brazilian divinities - entities that are archetypes of Brazilian society, such as old black slaves (pretos velhos) or indians (caboclos) in Umbanda, as well as orixás (gods) in the case of Candomblé - are summoned to come to the presence of the living. These spirits talk with a Brazilian accent, through the mouth of their "horses", Portuguese who, for the most part, have never set foot in Brazil; through incorporation, common individuals become powerful entities that help others to solve life-crisis situations, as an informant has stated:

The whole process of becoming able to receive the entities was the most fascinating experience in my life; learning to be possessed, my bori and feitura... and then be able to do something, really help people $[\ldots]$ it is something I had never felt in the Catholic church [...]. And also, my medium capacities were something that I could never talk about. I always felt and saw things, ever since I was a child. But the [Catholic] priest in my parent's church always said those were things of the devil, and we should pay no attention..." [Sara, 30, security guard]

Not only spirits, but also goods travel across the ocean. In the diaspora, the importation of herbs, leaves, drinks and other goods used in the rituals and therapies from the original home-grounds is intended, and many pais de santo and their followers travel to Brazil, returning with luggage full of such items. When it is not possible to use the original ones, the knowledge of the pai de santo is put to proof, since he has to know how they can be replaced by the local herb most similar to the original one, taking previous care to identify the medical properties of the plant. ${ }^{23}$

The example of the plasticity within such rituals also touches upon other ways of adapting to the new environment. For instance, cult leaders determine that the initiation period must be shortened, so that individuals are not

23 Such is the case of Mãe Virgínia, who uses her creativity to replace Brazilian herbs by others that she can find in Portugal (Pordeus Jr. 1997: 12). 
absent from their jobs, or that the need to shave the head of the initiated can be skipped, since individuals would be unable to proceed with their daily lives if this happened: "Here in Portugal, people are not used to such things. This is not Brazil nor Africa. If I had my iaôs ${ }^{24}$ scraped, how could they return to work? Nowadays, one needs to pay attention to these things." [J., 59 years old, pai de santo]

This same cult leader talks proudly of the fact that his terreiro

... has mostly young people, many of whom come for help, even young gay couples, and the spirit of Umbanda is to accept all this; Umbanda and Candomblé - and we, as persons responsible for the cults - have to make things change in Portugal and people who come here are taught to accept everything. [J., 59 years old, pai de santo]

Yet another one emphasizes the medium/high socio-cultural background of the followers: "We have all sorts of people here, from doctors and professors, psychologists, nurses $[\ldots]$ everyone feels well here [...] they feel at home; we help everyone, regardless of color, religion or status." [J., 59 years old, pai de santo]

Such ways of adapting to a new environment once again touch upon the issue of the differences in cults and the type of therapies performed in the terreiros, more embedded in the religious principles of Umbanda or closer to the African original matrix, and the cult leader's assessment of the degree of acceptance of certain practices: "Here in Portugal people are not used to have blood running down their faces. Why do we have to insist on this? The bori can sometimes take place without the sacrifice of animals, if people are sensitive to this..." [J., 59 years old, pai de santo]

These adaptations rely also on the creative capacity of the cult leader, and most of them talk about "their own way of doing things", calling upon individual knowledge they have acquired through time and through their successive initiations and learning.

Either way, what is invoked is the relation with one of the sources of such religions, Brazil or Africa. It is as if migration, the travelling from one place to another, acts as an enhancing experience for both individuals and for therapies, making them more visible and powerful. Many cult leaders were also persons who came to the terreiro for help, and, with time, themselves became believers, accepted his/her mediumship and ended up going through all the initiation rituals, thus shifting from a subservient position to an empowered one - as Maggie (2001) mentions in her analysis of the separations between mediums 
and clients in the cult. Such was the case of Mãe Virgínia. She started the chain of reproduction of these cults in Portugal by being a returning migrant herself, and thus bringing with her migrating therapies. The empowerment that her initiation in Brazil gave her can only be compared with the empowerment that Brazil (or Africa) gives nowadays. But, on the other side of the continuum, also the Brazilian cult leaders who travel to Portugal reinforce their prestige back home, in Brazil, since they become known as being so good in their role that they even cross the ocean to help people overseas.

This "empowerment triangle" is possible nowadays through the creative use of the new technologies. In her biography and booklets, Mãe Virgínia talks about the importance of setting down in writing all the principles and therapies of her Umbanda Omolocô, and considers this proselytism an important way to diffuse and spread the word of the orixás and do good on Earth. She also refers, as many anthropologists have done (Silva 1995; Capone 1999), the crucial role of other priests, as well as scholars and erudite persons who write about the basis and doctrines of these cults (Pordeus Jr. 1998, 2000).

I will take Pordeus Jr.'s suggestions even further, and state that if "writing is a way to construct a founding memory" (Pordeus Jr. 1998: 4, my translation), as the first mãe de santo did, nowadays, it is mainly through the Internet that diffusion of such "founding memories" takes place. In S.'s case, it was through the Internet that she found the Brazilian man who was to travel overseas and establish a new terreiro in Lisbon. Living in Madrid, and keeping a terreiro both there and in Lisbon, this priest sends all the monthly program for cult sessions, prayers, and all sorts of announcements, via web. In a town close to Lisbon, an Association for the Afro-Brazilian Culture was created and has been contacting anthropologists (like myself and others) to publish texts in a on-line journal they have recently started to publish; and the European Federation of Afro-Brazilian Cults, currently under construction, also uses the Internet as the vehicle for diffusion and communication among its members.

\section{CULTS AND THERAPIES IN THE ATLANTIC TRIANGLE: \\ PORTUGAL, BRAZIL AND AFRICA}

Based upon the data presented above, we may conclude that the success of the Afro-Brazilian religions in Portugal is part of a phenomenon that goes beyond the life in the terreiros and encompasses a more general variety of what is listed in the Portuguese newspapers advertisements as the "esoteric" field - specialists that publicize their expertise and training in Brazil or in Africa -, and is also part of the of re-composition of the religious field that accompanied the migration movements. Afro-Brazilian cults are successful because they overlap with two tendencies familiar and dear to the Portuguese, the old traditional healers and the Catholic matrix. One's individual path within the cults 
reproduces what goes on at a larger scale, as both cult leaders and followers often start in Umbanda, closer to those original matrixes, and later move on to Candomblé, perceived as more connected to African roots. On the other hand, these Afro-Brazilian cults offer certain things that neither the old popular religious practices nor the Catholic church were able to offer to the individuals that embrace the former: the ability to instrumentalize and manipulate deities to solve their life-crisis situations, but also the possibility of enacting themselves divine roles, and therefore to become empowered.

Brazilian religious re-constructions of the original African cults, incorporating spiritualism from late $19^{\text {th }}$-century France as well as indigenous practices, and African re-constructions of a real or symbolic relationship to Africa thus provide the basis for the re-elaboration of the "Portuguese Afro-Brazilian cults", which skilfully adapt to their new European environment.

Religious complexes where healing is central often act, as Fernando G. Brumana states, as therapeutic agencies where the official ones have failed (Brumana 1997: 11). If the desire for a closer relation with the divine as a means to solve life-crisis situations has always been there, the fact is that migrants and migration have played a decisive role in this re-composition of the Portuguese religious field. We can then see migration as a "transforming experience that turns travelers into exceptional people, endowed with charismatic power" (Bordonaro 2009). In a globalized world on the move, the reconstruction of the esoteric/religious fields and their cults uses those very same aspects as a means of empowerment: an exotic origin is thus a means of empowerment for individuals who originally were, as a result of their marginal condition of foreigners and migrants, estranged, dislocated and powerless.

Several authors have emphasized how the "roots" are used to align identities in the diaspora (Clarke 2004 in Capone 2004b: 11) and how spaces where migrants gather are arenas for continuous negotiation of individual and collective identities (Saraiva 2008). In the present case, migrants try to attain power by acting in a scenario that involves incorporating the fragilities of human existence in life-crisis situations, and by invoking their very same condition of migrants, and travelers, continuously moving, in reality or symbolically, between spaces - Africa, Brazil and Portugal - as an authoritative claim. 


\section{REFERENCES}

BARRETO, António (ed), 2005, Globalização e Migrações. Lisbon, Imprensa de Ciências Sociais.

BARROS, José, and Maria Lina TEIXEIRA, 1989, “O código do corpo: inscrições e marcas dos orixás", in Carlos Marcondes de Moura (ed.), Meu Sinal Está no Teu Corpo: Escritos sobre a Religião dos Orixás. São Paulo, Edicon/EDUSP, 36-62.

BASTOS, Cristiana, 2001, "Omulu em Lisboa: etnografias para uma teoria da globalização", Etnográfica, 5 (2): 303-324.

BASTOS, José Gabriel Pereira, and Susana Pereira BASTOS, 1999, Portugal Multicultural: Situação e Identificação das Minorias Étnicas. Lisbon, Fim de Século.

—, 2006, Filhos Diferentes de Deuses Diferentes. Lisbon, ACIME.

BIRMAN, Patrícia, 1985, O Que é Umbanda. São Paulo, Editora Brasiliense.

BLANES, Ruy, 2009, "Remembering and suffering: memory and shifting allegiances in the Angolan Tokoist church", Exchange, 38: 161-181.

BORDONARO, Lorenzo, 2009, "Sai fora: youth, disconnectedness and aspiration to mobility in the Bijagós islands (Guinea-Bissau)”, Etnográfica, 13 (1): 125-144.

BOURDIEU, Pierre, 1971, "Genèse et structure du champ religieux", Revue Française de Sociologie, XII (3): 295-334.

BROWN, Diana, 1999, "Power, invention, and the politics of race: Umbanda past and future”, in Larry Crook and Randal Johnson (eds.), Black Brazil: Culture, Identity and Social Mobilization. Los Angeles, UCLA Latin American Studies Center, 213-236.

BRUMANA, Fernando Giobellina, 1997, La Metáfora Rota. Cadiz, Servicio de Publicaciones, Universidad de Cadiz.

BRUMANA, Fernando, and E. MARTINEZ, 1991, Marginália Sagrada. Campinas, Unicamp. CAMARGO, Cândido Procopio Ferreira de, 1961, Kardecismo e Umbanda. São Paulo, Ed. Pioneira. CAPONE, Stefania, 1999, "Les Dieux sur la Net: l'essor des religions", L'Homme, 151: 47-74.

—_, 2004a, A Busca de África no Candomblé: Tradição e Poder no Brasil. Rio de Janeiro, Pallas Editora.

— (ed.), 2004b, "Religions transnationales", Civilisations: Revue Internationale d'Anthropologie et de Sciences Humaines, 51.

CAPONE, Stefania, and Viola TEISENHOFFER, 2001-2002, "Devenir medium à Paris: Aprentissage at adaptation rituels dans l'mplantation d'un terreiro de candomblé en France", Psychopathologie Africaine, XXXI (1): 127-156.

CASTELO, Cláudia, 1998, "O Modo Português de Estar no Mundo": O Luso-Tropicalismo e a Ideologia Colonial Portuguesa (1933-1961). Oporto, Afrontamento.

DANTAS, Beatriz G., 1988, Vovó Nagô e Papai Branco: Usos e Abusos da África no Brasil. Rio de Janeiro, Graal.

ESPÍRITO SANTO, Moisés, 1990, A Religião Popular Portuguesa. Lisbon, Assírio \& Alvim.

FAVRET-SAADA, Jeanne, 1977, Les mots, la mort, les sorts. Paris, Gallimard.

FELDMAN-BIANCO, Bela, 2001, "Brazilians in Portugal, Portuguese in Brazil: construction of sameness and difference", Identities, 8 (4): 607-650.

FRIGERIO, Alejandro, 2004, "Re-africanization in secondary religious diasporas: constructing a world religion”, Civilisations: Revue Internationale d'Anthropologie et de Sciences Humaines - Religions Transnationales, 51: 39-60. 
FRY, Peter, 1982, Para Inglês Ver. São Paulo, Brasiliense.

—, 2005, A Persistência da Raça: Estudos Antropológicos sobre o Brasil e a África Austral. Rio de Janeiro, Civilização Brasileira.

GOLDMAN, Marcio, 2007, "How to learn in an Afro-Brazilian Spirit Possession Religion: ontology and multiplicity in Candomblé”, in David Berline and Rámon Sarró (eds.), Learning Religion: Anthropological Approaches. London, Berghan Books, 103-119.

GUILLOT, Maia, 2007, Les cultes afro-brésiliens: nouvelles dynamiques religieuses au Portugal, thesis project, Paris X-Nanterre.

GUSMÃO, Neusa, 2004, Os Filhos de África em Portugal: Multiculturalismo e Educação. Lisbon, Imprensa de Ciências Sociais.

KOSER, Khalid, 2003, New African Diasporas. London, Routledge.

LAHON, Didier, 1999, O Negro no Coração do Império: Uma Memória a Resgatar, Séculos $X V$-XIX. Lisbon, ME/Casa do Brasil.

MACHADO, Fernando, 2002, Contrastes e Continuidades: Migração, Etnicidade e Integração dos Guineenses em Portugal. Oeiras, Celta Editora.

MACHADO, Igor, 2002, "Cárcere público: os estereótipos como prisão para os brasileiros no Porto, Portugal”, Revista Temática: Revista dos Pós-Graduados em Ciências Sociais do IFCH, 10 (19/20): 120-152.

MAFrA, Clara, 2002, Na Posse da Palavra. Lisbon, Imprensa de Ciências Sociais.

MAGGIE, Yvonne, 2001, Guerra de Orixá: Um Estudo de Ritual e Conflito. Rio de Janeiro, Jorge Zahar.

MALHEIROS, Jorge, 2005, "Jogos de relações internacionais: repensar a posição de Portugal no arquipélago migratório global”, in António Barreto (ed.), Globalização e Migrações. Lisbon, Imprensa de Ciências Sociais, 251-272.

ORO, Ari Pedro, 1995, "A desterritorialização das religiões Afro-Americanas", Horizontes Antropológicos, 3: 69-79.

ORO, Ari Pedro, and Carlos STEIL (eds.), 1997, Religião e Globalização. Petrópolis, Vozes.

ORTIZ, Renato, 1988, A Morte Branca do Feiticeiro Negro: Umbanda e Sociedade Brasileira. São Paulo, Editora Brasiliense.

PADILLA, Beatriz, 2003, "Os novos fluxos migratórios: tipos e respostas no velho e no novo mundo", paper presented to the $8^{\text {th }}$ Metropolis International Conference, 15-19 September, Vienna.

PAIS, José Machado, 1994, Sousa Martins e Suas Memórias Sociais: Sociologia de Uma Crença Popular. Lisbon, Gradiva.

PAIS, José Machado, Manuel Villaverde CABRAL, and Jorge VALA (eds.), 2001, Atitudes Sociais dos Portugueses: Religião e Bioética. Lisbon, Imprensa de Ciências Sociais.

PEREIRA. Luís Silva, 2006, "Migração, resistência e rituais terapêuticos: religiões afro-brasileiras em território português", Os Urbanitas, 3 (4) (available at <http://www.aguaforte. com/osurbanitas4/PEREIRA2006.html>).

PINA CABRAL, João de, 1989, Filhos de Adão, Filhas de Eva: A Visão do Mundo Camponesa do Alto Minho. Lisbon, Dom Quixote.

PIRES, R., 2003, Migrações e Integração. Oeiras, Celta Editora.

PORDEUS JR., Ismael, 1997, "Espaço, tempo e memória na Umbanda luso-afro-brasileira", paper presented in the panel «MR06 - O candomblé e suas variantes regionais: história ritual e crenças» at the V Congresso Luso-Afro-Brasileiro, Universidade Federal da Bahia. 
PORDEUS JR., 1998, "La mise en texte de la mémoire de Omolocô, à Lisbonne", in François Laplantine et al., Récit et connaissance. Lyon, Presses Universitaires de Lyon, Montfort et Villeroy.

—, 2000, Uma Casa Luso-Afro-Portuguesa com Certeza: Emigrações e Metamorfoses da Umbanda em Portugal. São Paulo, Terceira Margem.

— - 2006, "Lava-pés na Umbanda portuguesa", paper presented to the V Congresso de Estudos Africanos do Mundo Ibérico - "África: Compreender Trajectos, Olhar o Futuro", 4-6 May, Covilhã, Universidade da Beira Interior.

—, 2009, Portugal em Transe. Lisbon, Imprensa de Ciências Sociais.

PREVitalli, Ivette, 2008, Candomblé Agora É Angola. São Paulo, Anablume.

QUinTINO, Celeste, 2004, Migrações e Etnicidade em Terrenos Portugueses. Guineenses: Estratégias de Invenção de uma Comunidade. Lisbon, Instituto Superior de Ciências Sociais e Politicas da Universidade Técnica de Lisboa.

SANCHIS, Pierre, 1983, Arraial, Festa de Um Povo: As Romarias Portuguesas. Lisbon, Dom Quixote.

SARAIVA, Clara, 2007, "African and Brazilian altars in Lisbon: some considerations on the reconfigurations of the Portuguese religious field", in N. Naro, R. Sansi-Roca and D. Treece (eds.), Cultures of the Lusophone Black Atlantic. New York, Palgrave Macmillan, 175-196.

—, 2008, "Transnational migrants and transnational spirits: an African religion in Lisbon”, Journal of Ethnic and Migration Studies, special issue edited by R. Grillo and Valentina Mazzucato, 34 (2), 253-269.

—, 2010, "Afrobrasilianische Rituale und Therapien in Portugal", in Hansjörg Dilger and Bernhard Hadolt (eds.), Medizin im Kontext: Krankheit und Gesundheit in einer Vernetzten Welt. Frankfurt A. M., New York, Peter Lang, 170-187.

SARRÓ, Ramon, 2009, “O sofrimento como modelo cultural: uma reflexão antropológica sobre a memória religiosa na diáspora africana”, in Luís Silva Pereira and Chiara Pussetti (eds.), Os Saberes da Cura: Antropologia da Doença e Práticas Terapêuticas. Lisbon, ISPA, 33-51.

SCHMIDT, Bettina, 2008, Caribbean Diaspora in the USA: Diversity of Caribbean Religion in New York City. Oxon, Ashgate.

SEF, 2009, Relatório de Imigração, Fronteiras e Asilo: 2008. Lisbon, Serviço de Estrangeiros e Fronteiras.

SILVA, Vagner Gonçalves da, 1995, Orixás da Metrópole. São Paulo, Vozes.

TEISENHOFFER, Viola, 2007, “Umbanda, New Age et psychothérapie: aspects de l'implantation de l'umbanda à Paris", Ateliers du LESC, n. ${ }^{\circ} 31$, Religions afro-américaines: nouveaux terrains, noveaux enjeux (online since July 132007 at <http//ateliers.revues.org/documents872.html>).

VALA, Jorge, 1999, Novos Racismos: Perspectivas Comparativas. Oeiras, Celta Editora.

VILAÇA, H., 2001, "Identidades, práticas e crenças religiosas", in José Machado Pais, Manuel Villaverde Cabral and Jorge Vala (eds.), Atitudes Sociais dos Portugueses: Religião e Bioética. Lisbon, Imprensa de Ciências Sociais, 75-128. 
Religiões afro-brasileiras em Portugal: bruxos, padres e pais de santo - Clara Saraiva - Instituto de Investigação Científica Tropical e CRIA/FCSH-UNL, Portugal • clarasaraiva@fcsh.unl.pt

Os cultos afro-brasileiros que entraram em Portugal nos últimos vinte anos são cada vez mais populares, com templos cheios de portugueses que por vezes se tornam eles próprios pais ou mães de santo. Muitos deles previamente católicos, alguns preferem a Umbanda, mais próxima dessa matriz católica, outros viram-se para o Candomblé e para práticas consideradas "mais africanas". Tendo como base o trabalho de campo conduzido em Portugal com seguidores e líderes destes cultos, este texto explora, a partir do trabalho pioneiro de Ismael Pordeus Jr., alguns aspectos do novo "sincretismo" português, o modo como estes cultos atraem os portugueses e os processos hermenêuticos de influências que circulam no triângulo África-Brasil-Portugal.

PALAVRAS-CHAVE: Umbanda, Candomblé, Portugal, religiões transnacionais, imigração, reafricanização. 